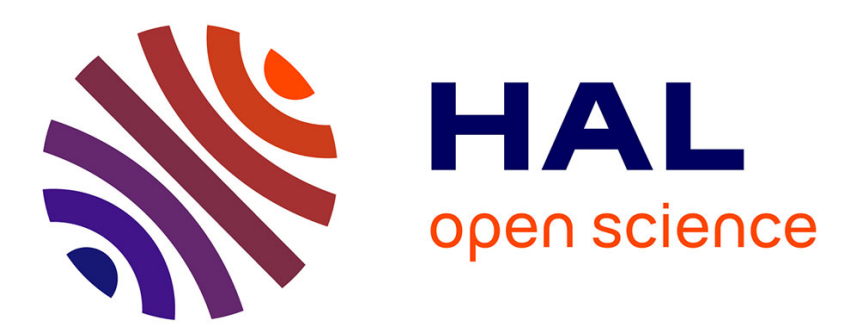

\title{
A scientific note on the first report of honeybee venom inhibiting Paenibacillus larvae growth
}

Natalia Fernández, Martín Porrini, Enrique Podaza, Natalia Damiani, Liesel Gende, Martín Eguaras

\section{- To cite this version:}

Natalia Fernández, Martín Porrini, Enrique Podaza, Natalia Damiani, Liesel Gende, et al.. A scientific note on the first report of honeybee venom inhibiting Paenibacillus larvae growth. Apidologie, 2014, 45 (6), pp.719-721. 10.1007/s13592-014-0289-y · hal-01234772

HAL Id: hal-01234772

https://hal.science/hal-01234772

Submitted on 27 Nov 2015

HAL is a multi-disciplinary open access archive for the deposit and dissemination of scientific research documents, whether they are published or not. The documents may come from teaching and research institutions in France or abroad, or from public or private research centers.
L'archive ouverte pluridisciplinaire HAL, est destinée au dépôt et à la diffusion de documents scientifiques de niveau recherche, publiés ou non, émanant des établissements d'enseignement et de recherche français ou étrangers, des laboratoires publics ou privés. 


\title{
A scientific note on the first report of honeybee venom inhibiting Paenibacillus larvae growth
}

\author{
Natalia J. Fernández ${ }^{1,2}$, Martín P. Porrini ${ }^{1,2}$, Enrique A. PodazA ${ }^{1}$, Natalia Damiani ${ }^{1,2}$, Liesel B. Gende ${ }^{1,2}$, \\ Martín J. Eguaras ${ }^{1,2}$ \\ ${ }^{1}$ Centro de Investigaciones en Abejas Sociales (ex-Laboratorio de Artrópodos), FCEyN, Universidad Nacional de Mar del \\ Plata, Funes 3350, Mar del Plata 7600, Argentina \\ ${ }^{2}$ CONICET, Rivadavia 1917, C1033AJ, Buenos Aires, Argentina
}

Received 7 January 2014 - Revised 21 March 2014 - Accepted 28 April 2014

honeybee venom/ Paenibacillus larvae / antimicrobial activity / Apismellifera

In the eusocial honeybee, Apis mellifera, worker bees use a stinging apparatus for defense. The sting is supplied with venom by glands localized in the abdomen. Honeybee venom (BV) is composed of at least 18 bioactive molecules, ranging from biogenic amines to proteins whose structure and function have been largely determined. These include peptides such as melittin, apamin, adolapin, and mast cell degranulating peptide; biologically active amines; enzymes as phospholipase A2 (PLA2); and a few nonpeptide components (Peiren et al. 2005; Matysiak et al. 2011). Melittin and PLA2 are the most abundant proteins, representing 50 and $12 \%$ of BV dry weight, respectively.

Furthermore, the venom gland has been recently reported as an important source of antimicrobial substances with proven antibacterial and antifungal action (Yu et al. 2012; Han et al. 2013). Nevertheless, data about the effects of BV on infectious pathogens of honeybees are previously absent from the literature. In this study, we proved that BV is able to inhibit the growth of a pathogenic bacterium affecting honeybee colonies.

Paenibacillus larvae is the causative agent of American foulbrood (AFB), the most destructive brood diseases of A. mellifera. Traditional control by chemotherapy has caused residues in hive products, and, more disturbingly, resistant pathogens (Evans 2003). These facts have driven studies on

Corresponding author: N. Fernández, njfernan@mdp.edu.ar Manuscript editor: Stan Schneider natural alternatives for AFB control. Thus, the aim was to analyze the effects of honeybee venom on $P$. larvae growth as well as its effect on adult bee survival after chronic exposure to BV.

$P$. larvae strains had been isolated from larvae with AFB from four apiaries in Argentina and PL33 (UB-CIDEFI) like reference strain. All strains were genotypically identified using PL2-Fw and PL2-Rv primers, and characterized like ERIC I with ERIC1R -and ERIC2 primers (Genersch et al. 2006).

For BV extraction, A. mellifera forager bees were obtained by covering the hive entrance and collecting them in their back flight. Venom sacs were dissected by pulling the sting apparatus from 30 bees. The resultant droplet of BV from the tip of the sting was placed on sterile slides, allowed to dry in dark for $24 \mathrm{~h}$, were collected by scraping and then weighed.

$P$. larvae isolates were exposed to serial dilutions of BV. One hundred microliters of Mueller-Hinton broth, yeast extract, and thiamine broth (Gende et al. 2008) were placed per well. BV stock solution and $50 \mu \mathrm{L}$ of the bacterial suspension $(0.5 \mathrm{McF}$ arland scale) were added to each well (serial dilutions from 200 to $1.56 \mu \mathrm{g} / \mathrm{mL}$ ). Incubation took place at $37^{\circ} \mathrm{C}$ for $48 \mathrm{~h}$. The inhibition of bacterial growth was confirmed by resazurin method (Damiani et al. 2014). Serial dilutions from 100 to $0.04 \mu \mathrm{g} / \mathrm{mL}$ of oxytetracycline (Fluka Analytical) were included as a positive control (Alippi et al. 2007). The lowest concentration of each substance that showed inhibition was considered as the minimal inhibitory concentration (MIC). The minimal bactericidal concentration (MBC) was estimated transferring $100 \mu \mathrm{L}$ 
Table I. Minimal inhibitory and bactericidal concentrations $(\mu \mathrm{g} / \mathrm{mL} \pm \mathrm{SE})$ of bee venom and oxytetracycline against Paenibacillus larvae strains.

\begin{tabular}{llllll}
\hline \multirow{2}{*}{ Strains } & \multicolumn{2}{l}{ Bee venom } & & & \multicolumn{2}{l}{ Oxytetracycline } \\
\cline { 2 - 3 } \cline { 5 - 6 } & MIC & MBC & & MIC & MBC \\
\hline PL33 & $8.33(2.08)$ & $10.42(2.08)$ & & $1.25(0)$ & $2.5(0)$ \\
Ayacucho & $8.33(2.08)$ & $8.33(2.08)$ & & $0.63(0)$ & $0.83(0.21)$ \\
Miramar & $3.12(0)$ & $4.16(1.04)$ & & $0.63(0)$ & $0.83(0.21)$ \\
Estafeta & $6.25(0)$ & $8.33(2.08)$ & & $0.52(0.11)$ & $3.75(1.25)$ \\
Cobo & $6.25(3.13)$ & $8.33(2.08)$ & & $0.11(0.03)$ & $0.52(0.11)$ \\
\hline
\end{tabular}

from MIC negative wells to plates with MuellerHinton broth, yeast extract, glucose, and sodium pyruvate agar, and incubated at $37{ }^{\circ} \mathrm{C}$ for $48 \mathrm{~h}$. Treatments were tested in triplicate. Statistical analyses were conducted in R 2.13.0 (R Development Core Team 2011). Linear mixed-model was performed to determine if MIC and MBC values varied due to treatments and strains (as random effect). Linear mixed effect models were fitted using maximum likelihood with nlme package.

The BV chronic toxicity was evaluated maintaining adult bees under short-term consumption. Newly emerged bees from capped brood combs were confined. Three replicates of 25 bees were supplied ad libitum these diets: $0 ; 100 ; 500$; and $1,000 \mu \mathrm{g} / \mathrm{mL}$ of BV powder in sugar syrup $60 \%(w / v)$, and were replaced daily. Survival curves plotting the number of live bees per group versus time were made. The Gehan-Breslow nonparametric test was performed to determine significant differences in survival curves. Pairwise multiple comparisons were made with the Holm-Sidak method $(\alpha=0.05)$.

Table I shows MIC and MBC values for BV and oxytetracycline against the bacterial strains. Strains responded significantly different to the treatments (MIC: $t=4.01 ; d f=20 ; P=0.0007$; and MBC: $t=3.74$; $d f=20 ; P=0.0013)$. From the random effect analysis significant differences among strains were not detected in each individual treatment. Furthermore, oral ingestion of BV did not cause significant mortality of adult bees $\left(\chi^{2}=3.831 ; d f=3 ; P=0.28\right.$; Fig. 1$)$.

As an alternative to the burning of infected hives, antibiotic oxytetracycline is currently used in AFB control in honeybee colonies. However, its intensive use resulted in oxytetracycline-resistant $P$. larvae isolates (Alippi et al. 2007; Evans 2003). In previous years, some natural substances have been tried as unconventional treatments for this disease. We report the results of the first study on the potential use of $\mathrm{BV}$ as an antimicrobial agent for AFB control. Results indicate that BV had in vitro activity against
P. larvae vegetative cells, requiring very low concentrations to inhibit its growth (MIC values from 3.12 to $8.33 \mu \mathrm{g} / \mathrm{mL}$ ). The BV was a 12 - and 50 -fold better antimicrobial than essential oils (Gende et al. 2008) and botanical extracts (Damiani et al. 2014), respectively.

Indeed, as BV is present on the cuticle of adult bees and on comb wax, it may act as a social antiseptic device (Baracchi and Turillazzi 2010). Lytic antibacterial and bacteriostatic activity against Gram-negative and Gram-positive bacteria has been reported for some peptides from BV and refused for others (Baracchi et al. 2013; Li et al. 2006; Van Vaerenbergh et al. 2013). Furthermore, the mode of action for BV against Gram-positive bacteria needs to be understood in order to determine its potential value as a natural treatment of AFB.

More studies are needed to confirm these promising findings. For example, exposure bioassays of

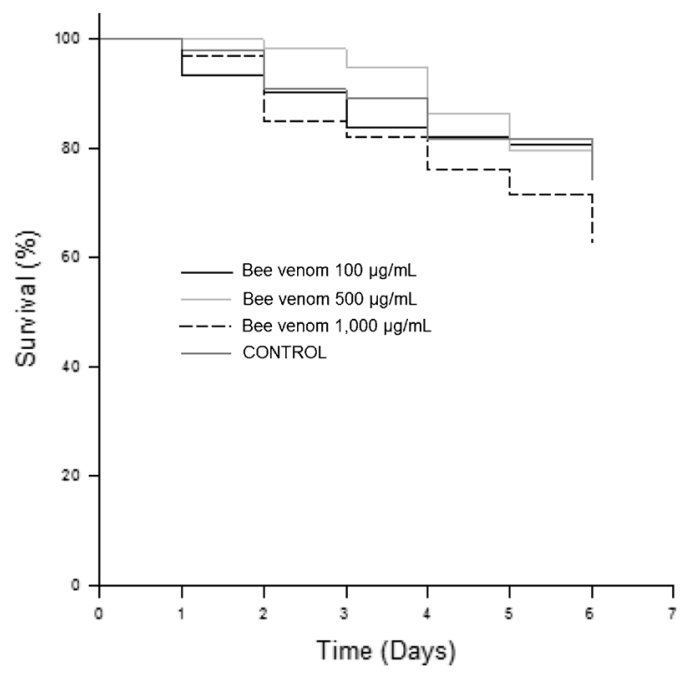

Figure 1. Survival curves for bees fed with bee venom. 
infected larvae to different BV doses or doses of single antimicrobial peptides from BV are a reliable approach to determine possible changes in the midgut environment that might inhibit $P$. larvae growth.

This research also constitutes the first record of oral administration of BV to an invertebrate biological model. No lethal or behavioral effects on bees after a week of ingesting BV were revealed. High doses of $\mathrm{BV}$ proved much less toxic for bees than some botanical extracts (Damiani et al. 2014). Further studies should be conducted to determine the toxicological risks and the optimum dosage of $\mathrm{BV}$ or the use of single antimicrobial peptides (i.e., Melittin) for field assays. BV extraction has become a standardized practice, characterized for being safe, simple, and causing no harm to bees. It would be interesting to investigate its effect on other apicultural diseases.

\section{ACKNOWLEDGMENTS}

We thank Dr. J. Nuñez for statistical analyses and K. Coonrod for grammar corrections. This study was supported by PICT Project $\mathrm{N}^{\circ} 1625 / 11$ (ANPCyT) to LG and Exa Project $N^{\circ} 579 / 12$ to ME (UNMDP), Argentina.

Note scientifique: données préliminaires sur le venin d'abeille comme inhibiteur de développment de Paenibacillus larvae

Eine wissenschaftliche Notiz zum ersten Befund über die Hemmung des Wachstums von Paenibacillus larvae durch Honigbienengift

\section{REFERENCES}

Alippi, A., López, A., Reynaldi, F., Grasso, D., Aguilar, O. (2007) Evidence for plasmid-mediated tetracycline resistance in Paenibacillus larvae, the causal agent of a honey bee larval disease. Vet. Microbiol. 125, 290-303

Baracchi, D., Turillazzi, S. (2010) Differences in venom and cuticular peptides in individuals of Apis mellifera (Hyme- noptera: Apidae) determined by MALDI-TOF MS. J. Insect Physiol. 56, 366-375

Baracchi, D., Mazza, G., Michelucci, E., Pieraccini, G., Turillazzi, S., Moneti, G. (2013) Top-down sequencing of Apis dorsata apamin by MALDI-TOF MS and evidence of its inactivity against micro-organisms. Toxicon 71, 105-112

Damiani, N., Fernández, N., Porrini, M., Gende, L., Álvarez, E., et al. (2014) Laurel leaf extracts for honeybee pest and disease management: antimicrobial, microsporicidal, and acaricidal activity. Parasitol. Res. 113, 701-709

Evans, J. (2003) Diverse origins of tetracycline resistance in the honey bee bacterial pathogen Paenibacillus Larvae. J. Invertebr. Pathol. 83, 46-50

Gende, L., Floris, I., Fritz, R., Eguaras, M. (2008) Antimicrobial activity of cinnamon (Cinnamomum zeylanicum) essential oil and its main components against Paenibacillus larvae. B. Insectol. 61, 1-4

Genersch, E., Forsgren, E., Pentikainen, J., Ashiraliev, A., Rauch, S., Kilwinski, J., Fries, I. (2006) Reclassification of Paenibacillus larvae subsp. pulvifaciens and Paenibacillus larvae subsp. larvae as Paenibacillus larvae without subspecies differentiation. Int. J. Syst. Evol. Microbiol. 56, 501-511

Han, S., Lee, K., Park, K., Pak, S. (2013) Antimicrobial activity of honey bee venom against select infectious fish pathogens. N. Am. J. Aquacult. 75, 445-448

Li, W., Ma, G., Zhou, X. (2006) Apidaecin-type peptides: biodiversity, structure-function relationships and mode of action. Peptides 27, 2350-2359

Matysiak, J., Schmelzer, C., Neubert, R., Kokot, Z. (2011) Characterization of honeybee venom by MALDI-TOF and nanoESI-QqTOF mass spectrometry. J. Pharm. Biomed. Anal. 54, 273-278

Peiren, N., Vanrobaeys, F., de Graaf, D., Devreese, B., Van Beeumen, J., Jacobs, F. (2005) The protein composition of honeybee venom reconsidered by a proteomic approach. Biochim. Biophys. Acta 1752, 1-5

R Development Core Team (2011) R: A language and environment for statistical computing. $\mathrm{R}$ foundation for Statistical Computing, Vienna, Austria

Van Vaerenbergh, M., Cardoen, D., Formesyn, E., Brunain, M., Van Driessche, G., et al. (2013) Extending the honey bee venome with the antimicrobial peptide apidaecin and a protein resembling wasp antigen 5. Insect Mol. Biol. 22, 199-210

Yu, A., Kim, J., Park, G., Oh, S., Han, C., Lee, M. (2012) The antifungal activity of bee venom against Dermatophytes. J. Appl. Biol. Chem. 55, 7-11 